\title{
PENGARUH PEMBAKARAN BERULANG PADA LAHAN GAMBUT TERHADAP BEBERAPA KARAKTERISTIK TANAH DI DESA RASAU JAYA UMUM KABUPATEN KUBU RAYA KALIMANTAN BARAT
}

\author{
(The effect of repeat combustion on peatland on some characteristics of land in Rasau Jaya \\ Umum village district, Kubu Raya Kalimantan Barat)
}

\author{
Yuliana Astuti, Dwi Astiani, Ratna Herawatiningsih \\ Fakultas Kehutanan Universitas Tanjungpura Jalan Imam Bonjol, Pontianak 78124 \\ E-mail: yulianaastuti1234@gmail.com
}

\begin{abstract}
The National Disaster Management Agency (BNPB) identifies eight provinces considered prone to forest and land fires in Indonesia. Four provinces are in Sumatra and four are in Kalimantan, one of which is West Kalimantan. Forest and land fires seem to have become a disaster in West Kalimantan, especially every dry season. Burning activies in the preparation of land for agriculture in the village of Rasau Jaya General is still using a relatively simple technology, namely the method of "slash and burn". The impacts caused by the peat fire process are in the form of water vapor from the combustion process in the air so that smoke formed which is very thick, causes environmental pollution and can affect soil conditions such as physical and chemical properties of peat soils. The purpose of this study was to obtain information about the effects of repeated burning on peatlands on soil characteristics in Rasau Jaya Umum Village, Kubu Raya Regency, West Kalimantan. This research was conducted by survey method and carried out with purposive sampling on 3 research sites, which were on land that had repeated burning twice, 4 times and 5 times. Soil physical properties observed were peat maturity (fiber content), water content, soil moisture, water level and bulk density. The level of fertility of peatlands is influenced by the chemical nature of the soil. The chemical nature of the soil is one of the limiting factors for knowing nutrients in the soil that are beneficial for plant growth. Determination of the level of soil fertility in peatlands can be done by analyzing the chemical properties of the soil. Analysis of the soil chemical properties includes analysis of the main element content such as acidity $(\mathrm{pH})$, nitrogen $(N)$, phosphorus $(P)$, potassium $(K)$ and cation exchange capacity $(C E C)$. The physical properties of the soil consisting of the weight of the contents, the moisture content varies with different levels of burning, the higher the value of the weight of the contents, the more dense a soil and vice versa. In the value of water content, the amount of combustion influences the amount of ground water content, the more number of combustion, the value of water content also increases. Peat environmental conditions observed in the field consisted of soil moisture, soil temperature and ground water level measured for 7 days and obtained a mean value that also varied did not show its effect on the number of repeated fires. The chemical properties of peat soils on the number of repeated burning can increase and decrease each nutrient value consisting of $N, P, K$ and also CEC. Nutrients that increase in the amount of combustion are $p H, N$, and $C E C$ while the value of nutrients that decrease is $K$ and $P$. This shows that the greater the level of combustion, the $\mathrm{pH}, \mathrm{N}$, and CEC greater.
\end{abstract}

Keywords: peatlands, repeated burning, soil characteristics 


\section{PENDAHULUAN}

Dampak yang ditimbulkan dari proses kebakaran ini antara lain menyebabkan jumlah partikel di udara sangat tinggi yang berupa uap air dari proses pembakaran sehingga terbentuk asap yang sangat tebal dan berdampak sangat luas, tidak hanya berupa polusi lingkungan dan mengganggu kesehatan tetapi juga dapat mempengaruhi kondisi tanahnya seperti sifat fisik dan kimia tanah gambut. Provinsi Kalimantan Barat merupakan salah satu daerah yang rutin terjadi kebakaran. Berdasarkan data Monitoring System luas kebakaran hutan dan lahan di Kalimantan Barat tahun 2014 - 2019 mencapai 93.515,80 ha tahun 2015 menurun hingga tahun 2017. Namun tahun 2018 luas lahan yang mengalami kebakaran meningkat mencapai 68.311,97 ha dan menurun tahun 2019 mencapai 2.273,97 ha luas lahan. Perlu diketahui, bahwa di Desa Rasau Jaya Umum Kabupaten Kubu Raya Kalimantan Barat belum adanya data-data informasi mengenai pengaruh pembakaran berulang di lahan gambut terhadap beberapa karakteristik tanah, sehingga penelitian ini dapat diharapkan bermanfaat bagi masyarakat dan pengambil kebijakan dalam pengolahan lahan gambut untuk pertanian ataupun perkebunan. Salah satu daerah yang rawan kebakaran hutan dan lahan di Provinsi Kalimantan Barat adalah desa Rasau Jaya kabupaten Kubu Raya yang setiap tahunnya terdeteksi titik-titik hotspot yang tinggi. Menurut (Sunanto, 2008) secara umum kondisi fisik Desa Rasau Jaya terdiri dari hutan dan lahan yang didominasi tanah gambut serta mempunyai tingkat kelembaban tinggi dengan tata lahan dan tata guna lahannya berupa kawasan pertanian lahan kering (PLK) dan areal penggunaan lain (APL). Kondisi gambut Desa Rasau Jaya umum Kabupaten Kubu Raya Kalimantan Barat merupakan salah satu bukti bahwa kebakaran hutan dan lahan gambut banyak disebabkan oleh manusia, baik secara sengaja ataupun tidak sengaja. Desa Rasau Jaya umum mayoritas mata pencaharian sebagai petani, sehingga pada setiap lahan yang sudah selesai ditanami akan kembali dibakar dalam waktu yang ditentukan, pembakaran berulang dilakukan untuk membersihkan lahan yang akan ditanami kembali agar memudahkan petani dan menambahkan pupuk baru untuk tanaman selanjutnya setelah di panen. Pembakaran berulang yang telah di tentukan berdasarkan wawancara kepada beberapa masyarakat yang memiliki lahan pertanian sendiri serta berapa lama telah mengolah lahan tersebut.

Tujuan penelitian ini adalah mendapatkan data tentang pengaruh kebakaran berulang pada lahan gambut terhadap karakteristik tanah di Desa Rasau Jaya Umum Kabupaten Kubu Raya Kalimantan Barat. Manfaat penelitian ini diharapkan dapat memberikan informasi kepada masyarakat umum khususnya para petani yang akan menanam pada lahan gambut yang telah berulang kali mengalami kebakaran dan juga dapat dijadikan dasar dalam pengelolaan lahan gambut ke depan. 


\section{METODE PENELITIAN}

Penelitian ini telah dilakukan pada lahan gambut di Desa Rasau Jaya Umum Kabupaten Kubu Raya Kalimantan Barat. Penelitian ini dilaksanakan di lapangan mulai tanggal 21 - 27 September 2019 dilanjutkan dengan analisis tanah di Laboratorium Fisika Tanah dan Laboratorium Kimia dan Kesuburan Tanah Fakultas Pertanian Universitas Tanjungpura Pontianak. Alat yang digunakan pada penelitian ini adalah Peta lokasi penelitian 1 : 25.000, GPS, Termometer, Hygrometer, Bor tanah, Kamera, ATK, Plastik Packing, Spidol, Meteran, Ring Sampel, Kertas Label, Pisau Cutter.

Metode yang digunakan pada penelitian ini adalah metode survey dan dilakukan secara purposive sampling yaitu teknik penentuan sampel dengan pertimbangan tertentu.

\section{Prosedur Penelitian Lapangan}

\section{Pengambilan contoh tanah uji sifat} kimia

- Alat

- Bor tanah

- Kantong plastik

- Cara kerja

- Bor tanah sampai kedalaman 40 $\mathrm{cm}$

- Ambil tanah pada setiap titik pengamatan, diambil 2 sampel tanah di setiap lahan yang mengalami pembakaran berulang berulang dan totalnya 6 serta 1 sampel tanah diambil dari tanah yang tidak pernah mengalami pembakaran.
- Masukkan ke dalam kantong plastik dan diberi label

\section{Pengambilan contoh tanah uji sifat} fisika

- Alat

- Ring sampel

- Sekop/cangkul

- Pisau tajam dan tipis

- Cara kerja

- Ratakan dan bersihkan lapisan permukaan tanah yang akan diambil, kemudian letakkan silinder tegak lurus pada lapisan tersebut

- Gali tanah disekeliling silinder dengan sekop

- Kerat tanah disekeliling silinder dengan pisau dampai mendekati permukaan

- Tekan silinder sampai tiga seperempat bagiannya masuk ke dalam tanah

- Letakkan silinder lain tepat di atas tabung pertama, kemudian tekan lagi sampai bagian bawah silinder yang kedua ini masuk ke dalam tanah

- Silinder beserta tanah didalamnya digali dengan pisau atau sekop

- Pisahkan silinder pertama dan kedua secara hati-hati, kemudian ratakan tanah sesuai tabung

- Tutuplah tabung beserta tanahnya dengan plastik untuk mencegah penguapan.

\section{Prosedur Penelitian Laboratorium}




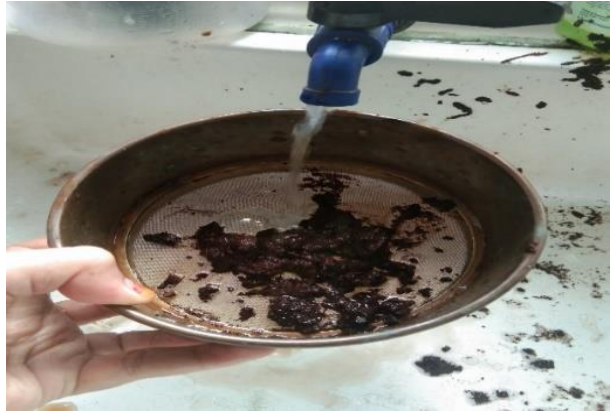

a. Penyaringan tanah gambut

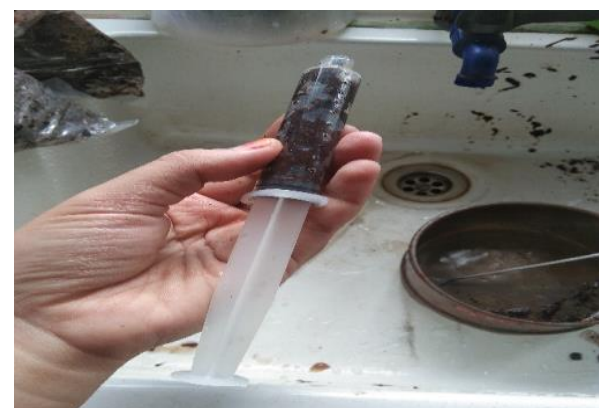

b. Penyuntikan untuk mengeluarkan air tanah

\section{Gambar 1. Proses menentukan kematangan gambut (The process of determining} the maturity of peat)

Kematangan gambut dilakukan di laboratorium fisika dan konservasi tanah dengan cara:

- Isi sampel tanah kedalam tabung suntik sebanyak $10 \mathrm{ml}$ tekan hati-hati dengan toraknya sehingga bahan tampak jenuh air dan udara yang tersekap dalam pori-pori tertekan keluar. Jangan sampai ada air ikut tertekan keluar.

- Kembalikan lagi bahan ini kedalam saringan dan dicuci dengan air yang mengalir sambil digosok-gosok diantara ibu jari dan jari telunjuk (jangan keras-keras), hingga air

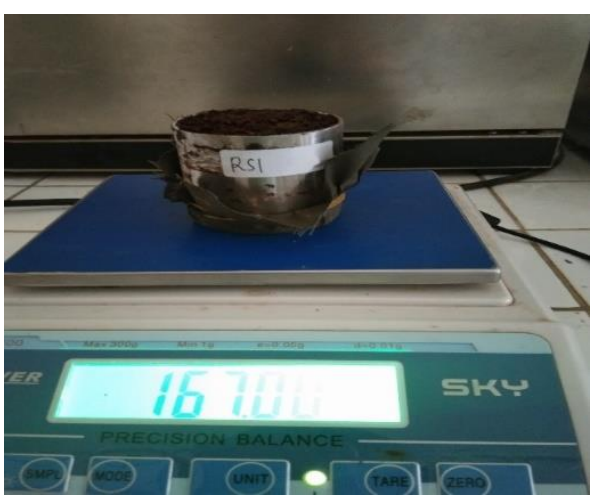

a. Penimbangan sampel sebelum di cucian tampak jernih. $\neg$ Kembalikan bahan kedalam tabungan suntik tadi secara merata, tekan hati-hati dengan toraknya air torak yang keluar sampai jenuh air seperti pada langkah kedua. Ukur volumenya (ml) dan hitung persennya terhadap volume awal.

Kerapatan isi (bulk density) adalah bobot kering suatu tanah dalam keadaan utuh dan dinyatakan dalam $\mathrm{gr} / \mathrm{cm} 3$.

Berikut adalah gambar sampel tanah gambut yang akan dihitung Bobot isi dan Kadar air nya.

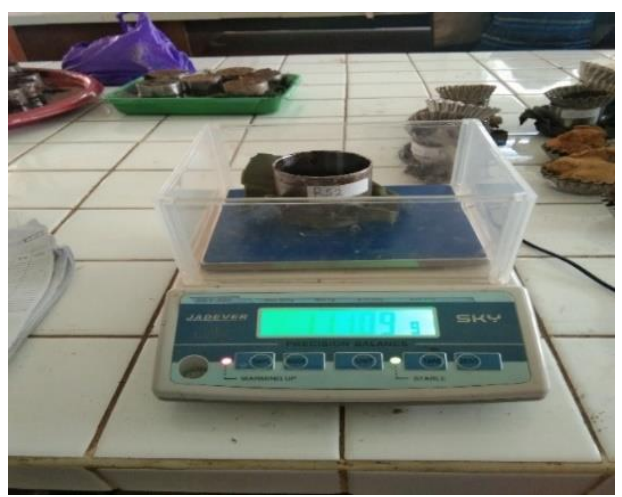

b. penimbangan sampel sesudah di oven oven

Gambar 2. Penimbangan sampel tanah (Soil sample weighing) 
- Pengamatan kedalaman muka air tanah di lapangan dilakukan pada setiap titik pengamatan dengan cara mengukur muka air tanah pada saluran airnya menggunakan meteran di 3 titik selama 7 hari.

- Suhu tanah dan kelembaban tanah dilakukan di 3 titik lahan gambut

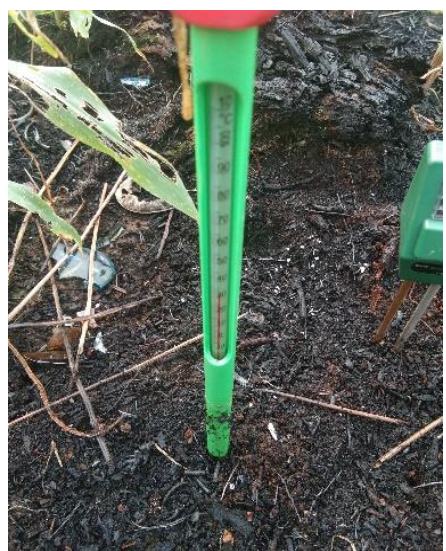

a. Pengukuran suhu tanah

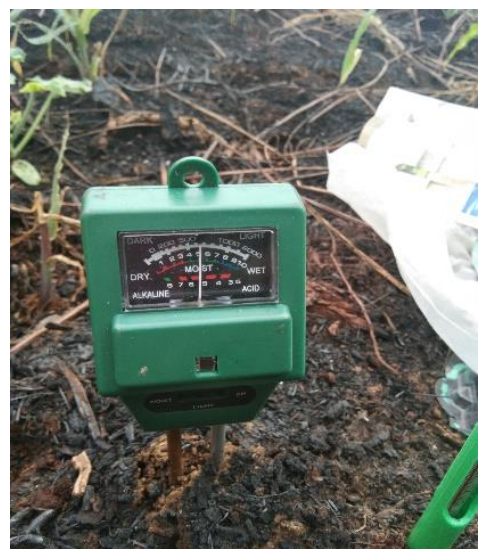

b. Pengukuran kelembaban tanah

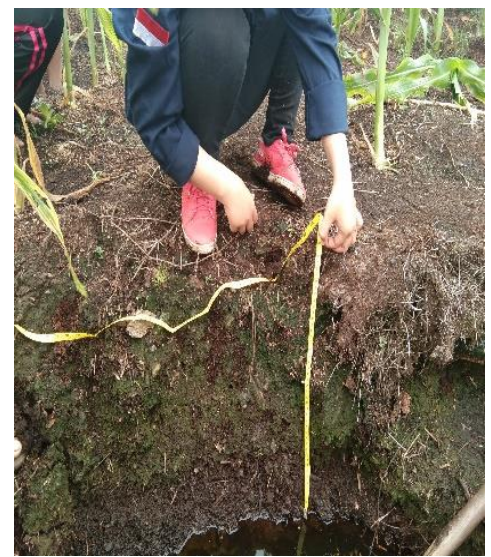

c. Pengukuran muka air tanah

Gambar 3. Kondisi lingkungan gambut (Peat environmental conditions)

\section{Analisis Data}

Data karakteristik tanah yang telah terkumpul selanjutnya digunakan untuk mengetahui dan membandingkan karakteristik sifat fisik dan kimia tanah dari 3 titik lahan gambut yang berbeda di antaranya 2, 4, dan 5. Setelah di dapatkan data dari hasil analisis laboratorium dan disajikan dalam bentuk table serta dijelaskan secara deskriptif. Menganalisa data rerata dari semua variabel yang diukur di setiap lokasi pembakaran berulang dan simpangan bakunya. Analisis data tersebut berupa simpangan baku/standar deviasi dan standar eror/ kesalahan baku.

\section{Standar Eror/ Kesalahan Baku}

Rumus Standart Error adalah

$$
S E=\frac{S D}{\sqrt{n}}
$$

Keterangan :

$$
\begin{array}{ll}
\mathrm{SE} & =\text { Standart error } \\
\mathrm{SD} & =\text { Standar deviasi atau simpangan } \\
\text { baku } & \\
\mathrm{n} & =\text { Banyaknya sampel }
\end{array}
$$

\section{HASIL DAN PEMBAHASAN \\ Sifat Fisika Gambut di Berbagai Pembakaran Berulang}

Sifat fisika tanah merupakan kunci penentu kualitas suatu lahan dan lingkungan. Lahan dengan sifat fisika yang baik akan memberikan kualitas lingkungan yang baik juga. Sifat fisika tanah diambil sebagai pertimbangan awal dalam menetapkan suatu lahan untuk pertanian (Yulnafatmawati et al., 
2007). Menurut Wasis (2005), sifat fisika tanah merupakan komponen yang sangat penting dalam penyediaan sarana tumbuh tanaman dan mempengaruhi kesuburan tanah yang akan menunjang pertumbuhan tanaman. Sifat fisik tanah gambut menjadi faktor yang sangat menentukan tingkat produktivitas tanaman yang diusahakan pada lahan gambut. Produktifitas tanaman menentukan kondisi aerasi (pertukaran udara di dalam tanah), drainase (mengatur air dalam tanah), daya menahan beban, serta tingkat atau potensi degradasi lahan gambut. Sifat fisika tanah yang diamati adalah kematangan gambut (kadar serat), kadar air, kelembaban tanah, tinggi muka air dan bobot isi (bulk density) (Agus dan Subiksa, 2008).

\section{Kematangan Gambut}

Hasil analisis tingkat kematangan gambut dapat dilihat pada tabel berikut:

\section{Tabel 1. Tingkat Kematangan Gambut (Peat maturity level)}

\begin{tabular}{ccccc}
\hline No. & Titik pembakaran & $\begin{array}{c}\text { Kadar Serat } \\
\text { Utuh }(\boldsymbol{\%})\end{array}$ & $\begin{array}{c}\text { Kadar serat } \\
\text { Gosok (\%) }\end{array}$ & $\begin{array}{c}\text { Tingkat } \\
\text { Kematangan } \\
\text { utuh }\end{array}$ \\
\hline 1. & Pembakaran 2 kali & 42,00 & 33,33 & Hemik \\
2. & Pembakaran 4 kali & 60,00 & 75,00 & Hemik \\
3. & Pembakaran 5 kali & 30,00 & 53,33 & Saprik \\
\hline
\end{tabular}

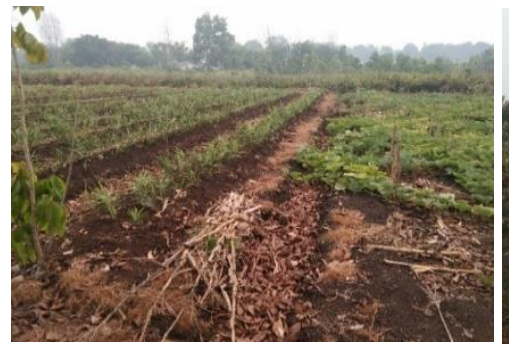

a. Pembakaran $2 \mathrm{X}$

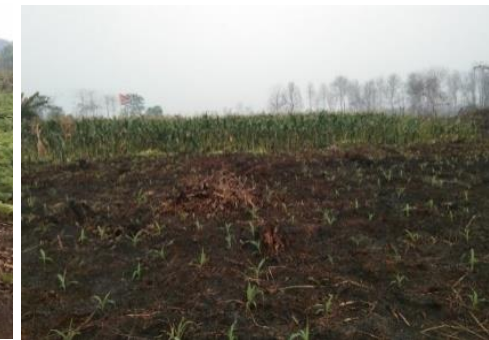

b. Pembakaran $4 \mathrm{X}$

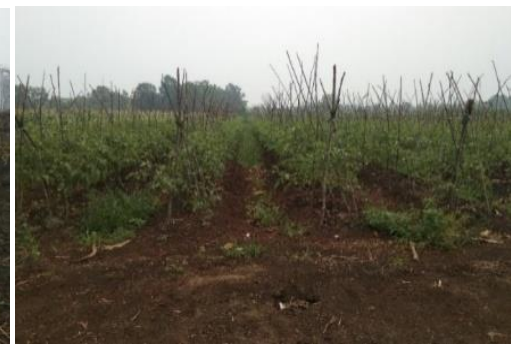

c. Pembakaran 5X

\section{Gambar 4. Lokasi penelitian}

Menurut Notohadiprawiro (1983), tingkat kematangan gambut terdiri dari kadar serat utuh dan kadar serat gosok. Kadar serat utuh menunjukkan keadaan serat gambut pada saat ini dan kadar serat gosok menandakan kemungkinan terjadinya proses dekomposisi lanjutan.

Berdasarkan Tabel 1, kematangan gambut utuh di titik pengamatan yang mengalami 2 kali pembakaran dan 4 kali pembakaran yaitu hemik (setengah matang). Tingkat kematangan hemik (setengah matang) yaitu kandungan serat yang tertinggal dalam telapak tangan setelah pemerasan adalah kurang dari tiga per empat sampai seperempat bagian atau lebih. Gambut yang mengalami 5 kali pembakaran termasuk dalam tingkat kematangan gambut saprik (matang). Tingkat kematangan saprik yaitu kandungan serat yang tertinggal di telapak tangan setelah pemerasan adalah kurang dari seperempat bagian. Tingkat dekomposisi pada lapisan gambut di 
lapisan atas dan di atas muka air tanah lebih tinggi atau lebih lanjut daripada lapisan gambut di bawah muka air tanah. Berdasarkan penilaian terhadap perubahan kematangan gambut, maka faktor utama yang mempengaruhi adalah tinggi muka air tanah (Suwondo et al, 2011). Gambut saprik mempunyai kemampuan menyimpan air lebih kecil, tetapi mempunyai daya pegang air yang lebih kuat dibandingkan gambut hemik dan fibrik dan sebaliknya.

Berdasarkan tingkat kematangannya atau dekomposisi bahan organik dibedakan tiga macam yakni, bahan organik dengan tingkat dekomposisi awal disebut bahan organik fibrik, jaringan - jaringan (fibers) tumbuhan masih nampak jelas (mudah dikenal), bahan organik hemik, bahan organik sekitar separuh (hemi= separuh/pertengahan) telah mengalami dekomposisi, dan bahan organik saprik, sebagian besar bahan organik telah mengalami dekomposisi. Cara lain untuk membedakan tingkat kematangan / pelapukan tanah gambut adalah dengan memperhatikan warna. Jenis tanah gambut fibrik akan memperlihatkan warna hitam muda (agak terang), kemudian disusul hemik dengan warna hitam agak gelap dan seterusnya saprik berwarna hitam gelap.

Dilihat dari kondisi fisik tanah, tanah gambut termasuk dalam golongan tanah organasol atau tanah histosol dengan berat jenis dalam keadaan lembab $<0,1 \mathrm{gr} / \mathrm{cm} 3$ dengan tebal $>60$ $\mathrm{cm}$ atau lapisan organik dengan berat jenis $>0,1 \mathrm{gr} / \mathrm{cm} 3$ dengan tebal $>40 \mathrm{~cm}$ (Soil Survey Staff, 2003), dengan sifat tanah biasanya jenuh air atau terendam sepanjang tahun kecuali telah direkaya melalui drainase atau yang dilewati oleh sungai. Tanah gambut sendiri memiliki kerapatan massa antara $0,1-0,3 \mathrm{gr} / \mathrm{cm} 3$ tergantung tingkat kematangannya. Gambut diklasifikasikan lagi berdasarkan berbagai sudut pandang yang berbeda, dari tingkat kematangan, kedalaman, kesuburan dan posisi pembentukannya. Harris (1998) menyatakan bahwa proses pengeringan gambut yang berlebihan akan cenderung merusak struktur ikatan antara air dan koloid (partikel terkecil dari bahan organik yang memiliki muatan) dari gambut. Keadaan ini dapat diartikan bahwa pada saat kering tidak balik terjadi, struktur ikatan fisik antara air dan koloid organik sudah mengalami kerusakan akibat pengeringan yang intensif. Pengeringan yang intensif pada gambut akan mempercepat proses pematangan bahan gambut dan menyebabkan permukaan gambut kehilangan kemampuan untuk mengikat air atau yang lebih dikenal dengan istilah hidrofobik sehingga pada temperature yang tinggi saat musim kemarau tiba gambut akan mudah terbakar (Suryadi et al, 2003). 
Bobot Isi (Bulk Density)

Tabel 2. Bobot Isi di Berbagai Pembakaran Berulang (Fill weights at multiple combustions)

\begin{tabular}{cccc}
\hline No. & Kode Sampel & Bobot Isi $\left(\mathbf{g r} / \mathbf{c m}^{\mathbf{3}}\right)$ & Standar Eror \\
\hline 1 & Pembakaran 2 kali & 0,16 & 0,09 \\
2 & Pembakaran 4 kali & 0,09 & 0,05 \\
3 & Pembakaran 5 kali & 0,11 & 0,06 \\
\hline
\end{tabular}

Bobot isi (bulk density) atau sering disebut juga dengan istilah berat volume merupakan sifat fisik tanah yang menunjukkan berat massa padatan dalam suatu volume tertentu. Kadar air yang tinggi menyebabkan (Bulk Density) menjadi rendah (Agus dan Subiksa,2008). Rendahnya BD gambut menyebabkan daya menahan atau menyangga beban menjadi rendah. Hal ini seringkali menyebabkan tanaman roboh.

Nilai bobot isi pada masing-masing titik pengamatan diukur pada kedalaman $40 \mathrm{~cm}$ dengan perhitungan berdasarkan berat kering oven (BKO) / volume ring. Tabel di atas menunjukkan nilai bobot isi (BD) bervariasi dengan tingkat pembakaran yang berbeda. Hasil ini belum menunjukkan Wasis (2005) kecenderungan perubahan nilai bobot isi karena nilai bobot isi pada lahan tanpa pembakaran berkisar antara $0,05-0,25$ $\mathrm{gr} / \mathrm{cm} 3$ (Susandi et al, 2015). Hal ini sependapat dengan (Defari et al, 2009) bahwa kebakaran menyebabkan gambut menjadi padat karena terjadinya peningkatan bobot isi oleh abu hasil pembakaran. Selain itu menjelaskan bahwa tanah yang terbakar akan mengalami hancurnya partikel tanah yang menyebabkan terjadinya pemadatan. Nilai bobot isi menunjukan tingkat kepadatan tanah, semakin tinggi nilai bobot isi maka semakin padat suatu tanah dan sebaliknya (Hardjowigeno, 1989 dalam Susandi et al, 2015).

Susandi et al, (2015) menyatakan bahwa tanah gambut memiliki bobot isi yang berkisar antara $0,05-0,25 \mathrm{gr} / \mathrm{cm} 3$ - Nilai bobot isi sebanding dengan tingkat dekomposisi. Semakin rendah nilai bobot isi maka tingkat dekomposisinya semakin lemah. Nilai bobot isi yang rendah diakibatkan oleh adanya rongga pada gambut yang dipengaruhi oleh adanya akar-akar tumbuhan maupun dari kayu pepohonan. Bobot isi gambut yang rendah mengakibatkan daya dukung tanah rendah sehingga tanaman mengalami kendala dalam menjangkarkan akarnya, akibatnya banyak tanaman tahunan yang tumbuh condong dan tumbang. Nilai bobot isi yang tinggi diakibatkan oleh terjadinya pemadatan dan pengaruh lapisan liat (Noor, 2001). Hasil penelitian ini menunjukkan bahwa banyaknya pembakaran berulang 2,4 dan 5 tidak mempengaruhi bobot isi tanah gambut. Kebakaran berulang tidak menjadi faktornya, faktor lain seperti kondisi tanah awal, intensitas kebakaran, dapat mempengaruhinya. 
Kadar Air Tanah (\%)

Tabel 3. Kadar Air di Berbagai Pembakaran Berulang (Moisture content in repeated combustion)

\begin{tabular}{cccc}
\hline No. & Kode Sampel & $\begin{array}{c}\text { Kadar Air } \\
(\% \text { Berat })\end{array}$ & Kadar Air (\%Vol) \\
\hline 1. & Pembakaran 2 Kali & 418,52 & 66,15 \\
2. & Pembakaran 4 Kali & 678,96 & 61,6 \\
3. & Pembakaran 5 Kali & 668,28 & 75,98 \\
\hline
\end{tabular}

Lahan gambut mempunyai kemampuan menyerap dan menyimpan air jauh lebih tinggi dibanding tanah mineral. Komposisi bahan organik yang dominan menyebabkan gambut mampu menyerap air dalam jumlah yang relatif tinggi. (Elon et al, 2011) menyatakan air yang terkandung dalam tanah gambut bisa mencapai 300-3.000\% bobot keringnya, jauh lebih tinggi dibanding tanah mineral yang kemampuan menyerap airnya hanya berkisar 20-35\% bobot keringnya. Gambut akan berubah menjadi hidrofob (menolak air) kalau terlalu kering.

Nilai kadar air ini sangat bervariasi dan tidak selaras dengan pernyataan Syaufina (2008) yang menyatakan bahwa semakin berat tingkat kebakaran lahan maka nilai daya mengikat air semakin rendah. Namun jika ditinjau dari kematangan gambutnya, kemampuan mengikat air terutama pada lahan gambut yang mengalami pembakaran 5 kali hasilnya sudah selaras, karena semakin matang gambut maka tingkat kemampuan mengikat air semakin tinggi, terutama pada musim kemarau atau lahan kering. Kebakaran yang besar akan menyebabkan bulk density meningkat yang menurunkan porositas dan laju infitrasi tanah yang pada akhirnya berdampak pada kemampuan mengikat air. Kadar air di dalam tanah harus cukup untuk memenuhi kebutuhan air tanaman atau berada dalam kondisi kapasitas lapangan, agar tanaman dapat tumbuh dengan optimal, sehingga menghasilkan produksi yang maksimal. Oleh karena itu, data kadar air tanah sangat diperlukan untuk menilai apakah kondisi kadar air dalam tanah tersebut sudah cukup untuk memenuhi kebutuhan air tanaman. Pada umumnya, tanaman akan mulai terganggu pertumbuhannya pada saat kadar air tanah <50 dari air tersedia, sehingga dapat menurunkan produksi. Noor (2001) menyebutkan bahwa kemampuan menyerap dan mengikat air pada ruang pori dari gambut tergantung pada tingkat kematangannya. Kemampuan tanah gambut untuk menyerap dan mengikat air pada gambut fibrik lebih besar dari gambut hemik dan saprik, sedangkan gambut hemik lebih besar dari saprik. Namun, pada gambut matang kemampuannya mengikat air pada pori halus lebih tinggi. Selain itu, Saribun (2007) menyatakan ketersediaan air tanah bukan hanya berdasarkan kematangannya saja, tetapi dipengaruhi juga oleh curah hujan atau air irigasi, kemampuan tanah menahan air, 
evapotranspirasi, dan tinggi muka air tanah.

\section{Kondisi Lingkungan Gambut}

Pengukuran sifat fisika tanah ini dilakukan selama 7 hari berturut-turut dengan 3 titik pengamatan yaitu 2 kali pembakaran, 4 kali pembakaran dan 5 kali pembakaran dapat dilihat pada tabel 4:

\section{Tabel 4. Rerata Kondisi Lingkungan Gambut (Average peat environmental} conditions)

\begin{tabular}{lcccccc}
\hline \multirow{2}{*}{ Kode Sampel } & Rata-rata & Rata-rata & \multicolumn{2}{c}{ Rata-rata } & \multicolumn{2}{c}{ Standar Eror } \\
\cline { 6 - 8 } & KT & ST & TMA & KT & ST & TMA \\
\hline Pembakaran 2 kali & 97,1 & 30,14 & 33,92 & 0,28 & 0,70 & 0,35 \\
Pembakaran 4 kali & 98,5 & 29,35 & 36,5 & 0,13 & 0,64 & 0,18 \\
Pembakaran 5 kali & 87,1 & 30,14 & 50,21 & 0,67 & 0,76 & 0,53 \\
\hline
\end{tabular}

Keterangan: $\mathrm{KT}=$ kelembaban tanah, $\mathrm{ST}=$ suhu tanah, $\mathrm{TMA}=$ tinggi muka air

Sifat fisika tanah merupakan kunci penentu kualitas suatu lahan dan lingkungan. Lahan dengan sifat fisika yang baik akan memberikan kualitas lingkungan yang baik juga. Sifat fisika tanah diambil sebagai pertimbangan dalam menetapkan suatu lahan untuk pertanian. Sifat fisika tanah gambut juga merupakan bagian dari morfologi tanah yang penting peranannya dalam penyediaan sarana tumbuh tanaman. Sifat fisika tanah yang dilakukan pengukuran secara langsung adalah kelembaban tanah, suhu tanah dan tinggi muka air.

Kelembaban tanah adalah air yang mengisi sebagian atau seluruh pori-pori tanah yang berada di atas (Jamulya dan Suratman, 1993). Kelembaban tanah pada suatu lokasi lokasi dipengaruhi oleh besarnya tingkat kadar air di dalam tanah. Kelembaban tanah merupakan salah satu faktor yang dapat digunakan sebagai indicator tingkat kekeringan suatu areal. Secara umum jika semakin tinggi kelembaban tanah suatu lahan semakin kecil peluang terjadinya kekeringan parameter lahan tersebut. Suhu tanah merupakan salah satu sifat fisik tanah yang sangat mempengaruhi proses - proses pelapukan pada lahan gambut. Secara umum, kelembaban suatu tanah sangat dipengaruhi oleh besarnya tingkat kadar air di dalam tanah. Kelembaban tanah merupakan salah satu faktor yang menentukan kekeringan suatu lahan. Jika semakin tinggi tingkat kelembaban tanah di suatu lahan maka semakin kecil peluang terjadinya kekeringan pada lahan tersebut. Dari hasil pengamatan pada tabel 10, nilai kelembaban tanah pada lahan yang mengalami pembakaran berulang yaitu bervariasi tetapi tidak bervariasi secara signifikan (87,1-98,5). Tingkat kelembaban tanah bervariasi ini sejalan dengan perubahan proses pertukaran energi matahari terutama yang melalui permukaan tanah. Artinya bahwa tingkat pembakaran yang berulang tidak berpengaruh terhadap kelembaban tanah. Suhu tanah merupakan faktor penting dalam menentukan prosesproses fisika yang terjadi di dalam tanah antara lain proses pelapukan bahan organik di tanah gambut. Kondisi tingginya temperatur dapat disebabkan perbedaan dilokasi terbakar lebih terbuka karena vegetasi yang banyak terbakar dan warna 
tanah bekas terbakar yang lebih gelap membuat penyerapan radiasi secara langsung ke permukaan tanah, sedangkan di lokasi tidak terbakar lebih tertutup oleh vegetasi sehingga dapat mengurangi radiasi yang di terima oleh tanah. Dari hasil analisis pada tabel 10, suhu tanah di berbagai pembakaran berulang tidak jauh berbeda secara nyata dan cukup bervariasi. Tinggi muka air tanah gambut dipengaruhi oleh drainase dan faktor iklim terutama curah hujan. Tinggi muka air tanah akan mempengaruhi kematangan dan dekomposisi tanah gambut (subsiden) dan menurut Las et al, (2008), pengaturan tata air makro maupun tata air mikro sangat mempengaruhi karakteristik lahan gambut. Berdasarkan tabel 10, tingkat pembakaran berulang, drainase dan curah hujan berpengaruh terhadap tinggi muka air tanah (TMA). Hal ini terlihat bahwa semakin banyak pembakaran berulang, maka besar nilai tinggi muka air. Namun kemungkinan bahwa ini perlu dikaji secara mendalam dan berurutan tentang perubahan drainase di seluruh hutan lahan terbakar.

\section{Sifat Kimia Gambut di Berbagai} Pembakaran Berulang

Hasil analisis sifat kimia gambut dapat dilihat pada tabel 5:

Tabel 5. Nilai Sifat Kimia Gambut Pembakaran Berulang(Value of repeated burning peat chemical properties)

\begin{tabular}{|c|c|c|c|c|c|c|c|c|c|c|}
\hline \multirow{2}{*}{$\begin{array}{l}\text { Kode } \\
\text { Sampel }\end{array}$} & \multirow{2}{*}{$\begin{array}{c}\text { Rata- } \\
\text { rata } \\
\text { Ph }\end{array}$} & \multirow{2}{*}{$\begin{array}{c}\text { Rata- } \\
\text { rata } \\
\mathbf{N}\end{array}$} & \multirow{2}{*}{$\begin{array}{l}\text { Rata- } \\
\text { rata } P\end{array}$} & \multirow{2}{*}{$\begin{array}{c}\text { Rata- } \\
\text { rata } \\
\mathbf{K} \\
\end{array}$} & \multirow{2}{*}{$\begin{array}{c}\text { Rata- } \\
\text { rata } \\
\text { KTK }\end{array}$} & \multicolumn{5}{|c|}{ Standar Eror } \\
\hline & & & & & & pH & $\mathbf{N}$ & $\mathbf{P}$ & $\mathbf{K}$ & KTK \\
\hline $\begin{array}{l}\text { Tidak } \\
\text { terbakar }\end{array}$ & 2,96 & 1,82 & 78,06 & 0,52 & 116,69 & & & & & \\
\hline P. 2 Kali & 2,58 & 1,87 & 81,68 & 0,34 & 115,21 & 0,23 & 0,01 & 18,77 & 0,02 & 2,80 \\
\hline P. 4 Kali & 3,10 & 1,87 & 313,26 & 0,46 & 116,82 & 0,37 & 0,02 & 16,74 & 0,04 & 1,00 \\
\hline P. 5 Kali & 3,24 & 1,89 & 206,64 & 0,66 & 115,43 & 0,06 & 0,01 & 34,82 & 0,16 & 0,69 \\
\hline
\end{tabular}

Ket: $\mathrm{pH}=$ Derajat keasaman, $\mathrm{N}=$ nitrogen, $\mathrm{P}=$ fosfor, $\mathrm{K}=$ kalium, $\mathrm{KTK}=$ kapasitas Tukar Kation

\section{Reaksi tanah (pH tanah)}

Menunjukkan sifat kemasaman dan alkalinitas tanah yang dinyatakan dengan nilai $\mathrm{pH}$. Nilai $\mathrm{pH}$ menunjukkan konsentrasi ion hidrogen $(\mathrm{H})$ dalam tanah, semakin banyak $\mathrm{H}$ dalam tanah maka semakin masam tanah tersebut. Nilai $\mathrm{pH}$ yang tinggi berbanding lurus dengan kapasitas tukar kation dan ketersediaan bahan organik (Rusdiana \& Lubis, 2012). Dari hasil analisis dapat dilihat bahwa nilai kapasitas tukar kation tidak berubah secara signifikan dan berbanding lurus dengan $\mathrm{pH}$. Hal ini menunjukkan bahwa semakin besar tingkat pembakaran, maka nilai $\mathrm{pH}$ semakin besar. Dalam artian bahwa semakin berat tingkat kebakaran lahan maka nilai $\mathrm{pH}$ tanah cenderung semakin tinggi.

\section{N (nitrogen)}

Pembakaran belum menunjukkan kenaikan nilai nitrogen. Namun bahwa semakin besar tingkat pembakaran lahan belum menunjukkan nilai nitrogennya. Berarti rendahnya $\mathrm{pH}$ juga berpengaruh terhadap nilai nitrogen. $\mathrm{pH}$ yang tergolong sangat asam mengakibatkan mikroorganisme perombak bahan organik tanah dan penambat nitrogen belum dapat bekerja secara optimal. Aktifitas mikroorganisme sangat dipengaruhi oleh kondisi pH tanah (Suwondo et al, 2011). 
Karena $\mathrm{pH}$ di gambut walaupun terjadi kenaikan atau peningkatan setelah terbakar, tetapi banyaknya pembakaran menghasilkan nilai $\mathrm{pH}$ yang rerata sangat asam. Unsur hara nitrogen memiliki peran yang sangat bagus berpengaruh terhadap pertumbuhan tanaman, artinya nitrogen merupakan sifat kimia tanah yang sangat dibutuhkan, meningkatnya umur pembukaan lahan gambut, kandungan nitrogen akan meningkat dengan tingkat dekomposisi. Nitrogen merupakan hara yang paling banyak mendapat perhatian, karena jumlah nitrogen yang terdapat di dalam tanah sedikit sedangkan yang di angkut tanaman berupa panen setiap musim cukup banyak. Menurut (Hakim et al, 1986) nitrogen masuk ke dalam tanah akibat dari kegiatan renik, baik yang hidup bebas maupun yang bersimbiosis dengan tanaman. Bahan Organik, pengaruh bahan organik terhadap sifat - sifat tanah dan akibatnya terhadap pertumbuhan tanaman adalah sebagai granulator yaitu memperbaiki struktur tanah, sumber hara, unsur hara N,P,K, unsur mikro, menambah kemampuan tanah untuk menahan air, menambah kemampuan tanahuntuk menahan unsur- unsur hara dan sumber energi bagi mikroorganiisme. Bahan organik umumnya ditemukan di permukaan tanah, jumlahnya tidak besar hanya 3-5 \% saja tetapi pengaruhnya terhadap sifat - sifat tanah sangat besar (Hardjowigeno, 2003).

\section{$\mathbf{P}$ (fosfor)}

Merupakan salah satu unsur hara penting dalam kandungan tanah gambut, kerena dapat meningkatkan kesuburan lahan pertanian. Apabila nilai $\mathrm{P}$ tinggi biasanya tanah akan semakin subur. Tingginya kandungan fosfor disebabkan karena hasil proses dekomposisi fosfor organik (mineralisasi) menjadi anorganik, karena banyaknya jasad mikro yang mati akibat kebakaran yang terjadi pada lahan gambut. Fosfor dalam tanah tidak semua dapat segera tersedia, hal ini tergantung pada sifat dan ciri tanah serta pengelolaan tanah. Fosfor tersedia didalam tanah dapat diartikan sebagai $\mathrm{P}$ tanah yang dapat diekstraksikan oleh air dan asam nitrat. Sedangkan kehilangan $\mathrm{P}$ dapat terjadi karena terangkut, tercuci dan tererosi. Hasil pengamatan nilai fosfor pada tingkat pembakaran cenderung berpengaruh terhadap kandungan fosfor di dalam tanah, Dibanding lahan gambut yang tidak terbakar terjadi peningkatan $\mathrm{P}$ tersedia, ditinjau dari tingkat ketersediaan pada lahan gambut secara keseluruhan tinggi baik yang tidak terbakar maupun tidak terbakar.

\section{K (kalium)}

Kandungan kalium pada lahan gambut kontrol (tanpa pembakaran) dan lahan gambut yang mengalami pembakaran berulang tidak berubah secara signifikan. Nilai tersebut menunjukkan bahwa semakin tinggi tingkat pembakaran maka semakin besar nilai kaliumnya. Keasaman tanah gambut cenderung makin tinggi jika gambut makin tebal.

\section{KTK (kapasitas tukar kation)}

Nilai kapasitas tukar kation hasil penelitian tergolong relatif tinggi. Hal ini disebabkan oleh karakteristik gambut yang secara alamiah KTK nya relatif tinggi. Kapasitas Tukar Kation merupakan kemampuan tanah dalam menyerap dan 
melepaskan kation yang dinyatakan sebagai total kation yang dinyatakan sebagai total kation yang dapat dipertukarkan. Nilai KTK tanah gambut sangat beragam tergantung pada tingkat dekomposisinya. KTK gambut terutama ditentukan oleh fraksi lignin dan substansi humat yang relatif stabil. KTK pada tanah gambut lebih besar dibandingkan tanah mineral, nilai KTK memegang peranan penting dalam pengelolaamn tanah dan dapat menjadi penciri kesuburan tanah. KTK tanah pada jumlah muatan negatif yang berada pada kontak jerapan (Hardjowegono, 1989). KTK tanah gambut berkisar dari $<50-100 \mathrm{cmol}(+) \mathrm{kg}^{-1}$ bila dinyatakan atas dasar berat, tetapi relatif rendah bila dinyatakan atas dasar volume (Noor, 2001).

\section{Kesimpulan}

Berdasarkan hasil penelitian dan pembahasan yang telah diuraikan pada bagian sebelumnya maka dapat disimpulkan bahwa kematangan gambut utuh di titik pengamatan yang mengalami 2 kali pembakaran dan 4 kali pembakaran yaitu hemik (setengah matang). Gambut yang mengalami 5 kali pembakaran termasuk dalam tingkat kematangan gambut saprik (matang).

Sifat fisik tanah yang terdiri dari bobot isi, kadar air nilainya bervariasi dengan tingkat pembakaran yang berbeda, semakin tinggi nilai bobot isi maka semakin padat suatu tanah dan sebaliknya. Pada nilai kadar air banyaknya pembakaran berpengaruh terhadap besarnya kadar air tanah, semakin banyaknya pembakaran maka nilai kadar air juga meningkat. Kondisi lingkungan gambut yang diamati di lapangan terdirri dari kelembaban tanah, suhu tanah dan tinggi muka air tanah diukur selama 7 hari dan didapat nilai rerata yang juga bervariasi tidak menunjukkan pengaruhnya pada banyaknya pembakaran berulang. Sifat kimia tanah gambut pada banyaknya pembakaran berulang dapat meningkatkan dan menurunkan masingmasing nilai unsur hara yang terdiri dari $\mathrm{N}$, $\mathrm{P}$, K dan juga KTK. Unsur hara yang meningkat pada banyaknya pembakaran adalah nilai $\mathrm{pH}, \mathrm{N}$, dan KTK sedangkan nilai unsur hara yang menurun adalah $\mathrm{K}$ dan P. Hal ini menunjukkan bahwa semakin besar tingkat pembakaran, maka nilai $\mathrm{pH}, \mathrm{N}$, dan KTK semakin besar.

\section{Saran}

Kebakaran lahan gambut mampu meningkatkan beberapa sifat fisik dan kimia tanah tetapi juga memberikan dampak negatif terhadap beberapa sifat fisik dan kimia tanah serta merusak sifat biologi tanah. Kebakaran lahan gambut pada hakikatnya merusak gambut sehingga tidak dianjurkan dSalam pembukaan lahan dengan cara dibakar.

\section{DAFTAR PUSTAKA}

Agus F, Subiksa IGM. 2008. Lahan Gambut: Potensi untuk Pertanian Dan Aspek Lingkungan. Balai Penelitian Tanah Dan World Agroforestry Centre (ICRAF). Bogor. Indonesia. 36 hal.

Depari EK, Tampang AB, Restu, Surnayanti WC, Adinugroho, Stepanus R. 2009. Dampak kebakaran hutan terhadap fungsi hidrologi. Laporan Penelitian. Mayor Silvikultur Tropika. IPB. Bogor. 
Hakim NM, Yusuf N, Lubis AM. 1986. Dasar-Dasar Ilmu Tanah. Lampung. Universitas Lampung.

Hardjowigeno, Sarwono. 2003. Klasifikasi Tanah Dan Pedogenesis. Jakarta. Akademika Presindo.

Jamulya, Suratman WS. 1993. Pengantar Geografi Tanah. Yogyakarta. UGM.

Las I. Nugroho K. Hidayat A. 2008. Strategi Pemanfaatan Lahan Gambut Untuk Pengembangan Pertanian Berkelanjutan. Jurnal Inovasi pengembangan Pertanian 2 (4): 295 298

Noor M. 2001. Pertanian Lahan Gambut dan Kendala. Konisius. Yogyakarta. Penerbit Kanisius.

Notohadiprawiro T. 1999. Tanah dan Lingkungan. Jakarta. Direktorat Jenderal Pendidikan Tinggi Departemen Pendididikan dan Kebudayaan.

Rusdiana O, Lubis RS. 2012. Pendugaan Korelasi Antara Karakteristik Tanah Terhadap Cadangan Karbon (Carbon Stock) Pada Hutan Sekunder. Jurnal Silvikultur Tropika 3 (1): 14-21

Saribun D. 2007. Pengaruh Jenis Pengunaan Lahan dan Kelas Kemiringan Lereng Terhadap Bobot Isi, Porositas Total dan Kadar Air Pada Sub-DAS Cikapundung Hulu. Jatinagor. Universitas Padjajaran.

Soil Survei Staff. 2003. Key to Soil Taxonomy. $9^{\text {th }}$ Edition. United States Department of Agriculture. Natural Resources Conservation Services.

Sunanto. 2008. Peran Serta Masyarkat dalam Pencegahan dan Penanggulangan Kebakaran Lahandi
Kecamatan Rasau Jaya. Tesis. Program Pasca Sarjana Universitas Diponegoro. Semarang.

Suryadi UE. Notohadisuwarno S. Maas A. 2003. Penilaian Hidrofibisitas Gambut Ombrogen Pontianak Akibat Variabilitas Muka Air Tanah dan Penggunaan Lahan Program Studi Ilmu Tanah. Yogyakarta. Program Pascasarjana Universitas Gadjah Mada. Susandi, Oksana, Arminudin AT. 2015. Analisis Sifat Fisika Tanah Gambut Pada Hutan Gambut di Kecamatan Tambang Kabupaten Kampar Provinsi Riau. Jurnal Agroteknologi 5 (2): 23-28.

Suwondo S. Sabiham, Sumardjo, Paramudya B. 2011. Pembukaan Lahan Terhadap Karakteristik Biofisik Gambut pada Perkebunan Kelapa Sawit di Kabupaten Bengkalis. Jurnal Natural Indonesia 14 (2): 143-149.

Syaufina L. 2008. Kebakaran Hutan dan Lahan di Indonesia Perilaku api. Penyebab dan Dampak Kebakaran. Malang. Bayumedia.

Wasis B. 2005. Kajian Perbandingan Kualitas Tempat Tumbuhan Antara Rotasi Pertama dan Rotasi Kedua Pada Hutan Tanaman Acacia Mangium Willd. Studi Kasus di HTI Musi Hutan Persada, Provinsi Sumatera Selatan. Disertasi. Bogor. IPB.

Yulnafatmawita, Luki U, Yana A. 2007. Kajian Sifat Fisika Tanah Beberapa Penggunaan Lahan di Bukit Gajabuih Kawasan Hutan Hujan Tropik Gunung Gadut Padang. Jurnal Solum Vol. IV (2): 49-61. 